\title{
PUBLIC ADMINISTRATION RECRUITMENT IN ALBANIA IN THE VIEW OF EU STANDARDS*
}

\author{
Andon KUME** \\ Olta QEJVANI***
}

\begin{abstract}
European integration is a very important process in Albania being accompanied with many requests that asks for implementing the right answers. One of these requests, in order to reach out the European values, is the fair recruitment in public administration Even though, the profile of employees in public administration is strongly related to the inside power of government and national framework, the public administration performance as a whole is a key dimension of being dressed with EU standards. The public administration reform, which started in 2013 is still a prolong process, which keeps improving also the recruitment in public administration. Basically, the most crucial changes are referred to civil service system. This paper aims to: analyze some issues of the approximation level of Albanian legislation towards recruitment according to EU standards; presenting some alternatives on how this process can be improved by strengthening institutional cooperation; giving some practical issues for recruitment in local governance, too.
\end{abstract}

Keywords: recruitment; civil service; civil servant; public administration

DOI: 53373/ REDS.2021.53.4.037

\section{Introduction}

In the fourth quarter of 2020, the employment rate for the population aged $15-$ 64 is $60.2 \% .^{1}$ On the other hand, there are $182.547,000$ working in the public administration. ${ }^{2}$ This part of population consists a very important group to be properly treated with the human rights principles, European values and standards in order that to further establish and improve a productive employment framework in our country. Meeting international standards, European values and human rights principles is a must for recruitment in public administration performance.

This paper follows a narrative methodology aiming to organize the information into this dimension: presenting which are the concrete EU requests, what is the approximation legal approach in this context and giving some examples or alternatives even in the local governance arena in regard to this issue. Going through

\footnotetext{
* Paper presented at the International Conference "The future of labor law after coronavirus" organized on-line by the Association for the Study of Professional Labor Relations on May 13 and 14, 2021

** Prof. As. Dr. Dean of Faculty of Political and Legal Sciences University 'Aleksander Moisiu', Durres *** PhDC, Faculty of Political and Legal Sciences University 'Aleksander Moisiu', Durres

${ }^{1} \mathrm{http}: / /$ www.instat.gov.al/media/8132/atfp-t4-2020.pdf, see INSTAT statistics for 2020, last seen in May 2021

${ }^{2}$ http://databaza.instat.gov.al/pxweb/sq/DST/START_TP_AD_ADQ/ADQ131/table/tableViewLayout2

/?rxid=9cd18158-1a05-4435-85e9-c50a485e50b9, see INSTAT statistics for 2020, last seen in May 2021
} 
theory of exploration will screenshot the current legal situation of this panorama even with some reflections where possible.

\section{EU legal standards and requests on recruitment in public administration}

One 'ironic' fact is that the Lisbon Treaty excludes civil service from the protection of EU legislation. Article 39, parag.4 highlights that 'the provisions of Lisbon Treaty for movement of people and employees does not apply for those in public administration'. Even though EU legislation considers and put in umbrella of national protections, the common approach is not missing out.

So, the way how EU speaks out for employment in public administration stands out into the terms of soft law. EU Programme for Employment and Social Innovation $(\mathrm{EaSI}),{ }^{3}$ is the common approach that EU has set up for considering public administration improvement in the heart of European Union. The Employment and Social Innovation (EaSI) programme is a financing instrument at EU level to promote a high level of quality and sustainable employment, guaranteeing adequate and decent social protection, combating social exclusion and poverty and improving working conditions.

This financial instrument does not put into the main focus the recruitment in public administration. Only the principles of human rights, decent job and other basic principles are referred and put into the attention of it. EU law, even though does not intervene on the inside approach of the countries, always calls out for respecting human rights and international standards even into the public sector.

Another way of calling and addressing of EU legislation is to non EU countries which are already on their road of integration. The progress reports from European Commission delivered for different elements of integration treat specifically the public administration reform (PAR). Based on the last progress report of EU Commission, ${ }^{4}$ the following table can explain the positive and what is still a need for achievement in improving the recruitment in public administration:

\begin{tabular}{|c|l|l|}
\hline No. & Achieved & Need to be improved \\
\hline 1 & $\begin{array}{l}\text { The Civil Service Law (CSL) provides a } \\
\text { solid basis for merit-based recruitment } \\
\text { and promotion. }\end{array}$ & $\begin{array}{l}\text { Due to a fragmented legislative } \\
\text { framework, there are not yet uniform } \\
\text { standards on merit based recruitment, } \\
\text { promotion and dismissal across the whole } \\
\text { public administration. }\end{array}$ \\
\hline
\end{tabular}

\footnotetext{
${ }^{3} \mathrm{https}: / /$ ec.europa.eu/social/main.jsp?langld=en\&catld=1081, last seen in May 2021

4 COMMISSION STAFF WORKING DOCUMENT, Albania 2020 Report, Accompanying the Communication from the Commission to the European Parliament, the Council, the European Economic and Social Committee and the Committee of the Regions 2020 Communication on EU Enlargement Policy, www.dap.gov.al , last seen in May 2021
} 
Revue europénnee du droit social

\begin{tabular}{|c|l|l|l|}
\hline 2 & $\begin{array}{l}\text { Overall transparency and fairness of } \\
\text { recruitment at the central level has } \\
\text { improved thanks to introduction of a full } \\
\text { digitalised recruitment and selection } \\
\text { process for the civil service, further } \\
\text { harmonisation of job descriptions, } \\
\text { improved quality of examinations and } \\
\text { organisation of recruitments. }\end{array}$ & $\begin{array}{l}\text { provisions regulating } \\
\text { recruitment for senior ranks needs to be } \\
\text { ensured. }\end{array}$ & $\begin{array}{l}\text { merit-based } \\
\text { mence }\end{array}$ \\
\hline 3 & & $\begin{array}{l}\text { Proper implementation of the CSL } \\
\text { requires more efforts at the local level. }\end{array}$ \\
\hline
\end{tabular}

The realization of a successful (PAR) Public Administration Reform has been a continuous request from EU institutions in order to reach out the standards. Comparing with the situation that EU does not intervene to the countries regarding to this issue, the monitoring approach and requests related to our country is set up into the terms of monitoring the integration, not monitoring the country behavior in regard to this dimension.

\section{Legal approximation and public administration reform in Albania}

The Public Administration Reform Special Group (PAR SG) was established to monitor the implementation of the Stabilization and Association Agreement (SAA), in order to provide a medium-term framework for a more structured dialogue on public administration, including local government. The European Commission has increased its emphasis on public administration reform in Albania and the Western Balkans, considering this reform among the key priorities of the enlargement strategy. The EU-Albania Public Administration Reform Special Group serves as the main platform for advancing the work of the Public Administration Reform, and aims to include this reform in the enlargement process. The meetings of this working group are co-chaired by the Head of the Unit for Albania, Bosnia and Herzegovina, the European Commission and the political representative of Albania responsible for pursuing public administration reform. ${ }^{5}$

Despite of these EU structures, the main responsibility remains in the shoulders of Albanian Public Administration to walk and run with the same standards like Europeans do. Screening process and approximation of legislation, is the first step of ensuring further integration for labor policy and issues. According to the National Plan for Integration $2016-2020,{ }^{6}$ there is no specific provision regarding to recruitment process to public administration. Only general laws and secondary acts

5 http://dap.gov.al/publikime/dokumenta-strategjik/298-public-administration-reform-special-group-parsg-eu-albania, last seen in May 2021

${ }^{6}$ http://www.dap.gov.al/images/DokumentaStrategjik/PKIE\%202016-2020.pdf, last seen in May 2021 
are being provided in this National Plan, meanwhile a specific and detailed analysis of recruitment process must be emphasized. In additional, there is no specific focus detailed and being explained to local governance recruitment system.

The lack of provision of recruitment process in public administration and especially to local governance public administration, does not clarify and raise out the proper alert for other stakeholders to deal with this issue. In Albania, since 2013 the whole legislative package for civil service is established according to EU requirements and laws (law for civil service and secondary legislation). On the other hand, even the Labor Code was improved according to EU standards recently. ${ }^{7}$ Even though this panorama shows up good premises of legal development and common approach, we recommend that a specific focus of recruitment (and employment in general) will need to be taken in the framework of strategies, National Action Plan or different institutional report.

We consider that not a proper legal analysis is realized in the framework of recruitment process. An additional recommendation would be the establishment of a proper law for youth employment in public administration (or at least a decision of Council of Ministers). Due to the fact that most of European countries and even Albania are suffering from brain drain, a possible legal mechanism: such the recruitment and employment of youth in public administration will help a lot to solve this dilemma.

One of our focus was even the role of institutional mechanisms that can push forward the approximation legislation with the terms of EU standards, specifically to:

- PAR SG group

- Commission on Approximation at Albanian Parliament

- Council of Ministers

- INSTAT

- Commissioner.

It is quite positive what these institutions have done so far in the framework of screening process, but there are still some alternatives that can be used for further improvement of integration process. Our recommendations would consist as following:

- An official coordination of PAR SG Group with Albanian Parliament and Council of Ministers. The combination of methodology that PAR SG obtains with the national concrete information that the Parliament and Council of Ministers have will lead to better legal and policy analysis, even in the terms of research.

- INSTAT must provide more statistics in details for employment and other aspects of local governance. The methodology and rhythm of EUROSTAT is a must into the process of integration.

- A more detailed information provided and worked from Commission on Approximation at Albanian Parliament. It has come the time that this overload work

\footnotetext{
${ }^{7}$ https://www.parlament.al/Files/Integrimi/ligj_nr_136_dt_5_12_2015_25080_1.pdf, Albanian Parliament narratives on approximation, last seen in May 2021
} 
of many documents and laws must be elaborated into concrete narratives and statistics.

- On the other way, the specific Ministry for Local Governance must take the lead of coordinating all the information regarding local and regional development in Albania.

- The Albanian representatives at the Congress of Local and Regional Authorities, Council of Europe must coordinate the information required in the framework of this membership, in order to provide the proper information to the Council of Europe realizing in this way their official commitment to this European (even not EU) structure.

- In additional, it would be strongly recommended that the Commissioner for Protection of Civil Service must provide in its own regulation the organization of a monitoring process in each of the municipalities once per yer. This practice has become to start, but in order to work more as a filter and identifying recruitment bad manners in local units, this must be established as a legal basis process. In this way, the municipalities must perceive and organize the implementation of civil service into the approach of the methods and requests of this institution.

\section{Recruitment in local public administration: some examples and reflections}

Lack of attention is paid towards recruitment in local public administration. Local and regional development remains also a crucial dimension of PAR in our country. According to the new legislation approved since 2013 in civil service, the management of recruitment process is realized from Human Resources Sector inside each local units. This legal provision contain a ratio legis because of the principle of self decentralization. On the other hand, due to the fragile way of functioning of local governance in our country, a common competent structure that can manage the recruitment process would also be useful.

European structures, on the other hand has set up principles and standards that local governance needs to face and to work on. So, Congress of Local and Regional Authorities, Council of Europe has set up rules and principles on how local governance can behave such as Resolution 441(2019), Recommendation 428 (2019). ${ }^{8}$ In these important documents, the establishment and proper function of integrity management structures in local governance 'Integrity Bureaux', composed of integrity councillors, to investigate suspected cases of misconduct in this area would best fit to the reality solution problems that local governance face in our country. Having a filter of dealing with recruitment process in local units would expand the problems of potential self isolation. In this way, local units can 'save' their own self ${ }^{8}$ https://rm.coe.int/fighting-nepotism-within-local-and-regional-authorities-governance-com/16809312c3,
last seen in May 2021 
governance, but at the other hand they can promote successful employment arena, developing the community.

Considering that in the near future, Albania can be a country member of EU, Committee of the Regions remains also an important stakeholder of local and regional development. According to this, local governance units in our country must be prepared to cooperate in the future with cross borders terms, facilitating and easily adapting other municipalities practices or even implementing projects according to EU standards. In this regard, having as much as possible the job descriptions or recruitment process just EU common procedures, will make local and regional development a successful history, too.

Even in this vague arena of recruitment development in local governance, a positive approach of managing and coordinating this in a national level is still present. The Council of Ministers, with the proposal of Ministry for Local Governance has approved the National Intersectoral Strategy for Decentralization and Local Governance 2015 - 2020. ${ }^{9}$ Among all, in this Strategy the recruitment process of Human Resources Management of each unit must be implemented and organized according international and national standards. Going in concrete details, the strategy aims to adapt manuals and instructions for local governance units. The strategy has set up this competence to Department of Public Administration (DoPA), Ministry for Local Governance and also to Human Resources Sector of each municipality, providing also the budget 2.100,000 ALL. So far, some manuals has been produced from DoPA, but still there are organized and perceived in general, without going in details to specific needs and issues for local governance. We find it immediate and necessary to bring recruitment in local public administration into the fullest vision of Albanian policy and legislation, producing also specific manuals for municipalities.

\section{Conclusions and recommendations}

1. EU request to implement a successful public administration reform must not perceived as a future intervention in our legal system, but as a monitoring process of integration road path towards EU.

2. There is a urgent need that the current Albanian institutional policy and documents can speak loudly and in details for the recruitment in public administration. Most of the legal analysis and screening process is focused in general terms to the employment dimension of public administration.

3. Recruitment in local governance must be brought up as a specific issue into the terms of Progress Reports, National Action Plan for Integration and different related documents that treat recruitment/employment in public administration.

\footnotetext{
9 https://www.bpe.al/sites/default/files/publications/Strategjia-ndersektoriale-per-decentralizimin-dheqeverisjen-vendore.pdf, last seen in May 2021
} 
4. An alternative on how local units can implement a successful process of recruitment in their public administration is the establishment of 'Integrity Bureaux', as a filter mechanism of possible nepotism, conflict of interests for community based needs.

5. The specific Commission for Albanian legislation approximation must bring the focus of local governance into the proper attention, by also asking for a more eficent cooperation between Council of Ministers (being the policy making body of our country).

6. INSTAT, as the main national institutional level that deals with statistics, must keep working now with the same indicators and methodology like EUROSTAT, in our framework to produce more statistics for employment in local communities.

7. The Commissioner must establish the practice of 'monitoring' the municipalities once per yer on the implementation of civil service legislation, specifically providing methodologies in regard of recruitment process.

\section{Bibliography:}

- INSTAT statistics for 2020

- National Action Plan for Integration 2016 - 2020

- National Intersectoral Strategy for Decentralization and Self Governance

- Progress Report 2020, COMMISSION STAFF WORKING DOCUMENT, Albania 2020 Report, Accompanying the Communication from the Commission to the European Parliament, the Council, the European Economic and Social Committee and the Committee of the Regions 2020 Communication on EU Enlargement Policy

- Recommendation 428 (2019), Congress of Local and Regional Authorities, Council of Europe

- Resolution 441(2019) Congress of Local and Regional Authorities, Council of Europe

- Law no. 152/2013 "On Civil Servant" as amended

- www.bpe.al

- www.coe.int

- www.cor.europa.eu

- www.dap.gov.al

- www.ec.europa.eu

- www.instat.gov.al

- www.ligjet.org

- www.parlament.al

- www.qbz.gov.al 